\title{
A Review of the Project Cycle and Project Implementation at the Third Tier Level of Government in Nigeria: A Theoretical Reflection
}

\author{
Stephen Ocheni, Ph.D. \\ Ministry of Foreign Affairs, Abuja \\ stephenocheni@yahoo.com \\ $+23480649596600$ \\ Moses Atakpa, Ph.D. \\ Head of Service, Kogi State, Nigeria \\ $+2348138916002$ \\ Basil C. Nwankwo, Ph.D.* \\ Professor and Dean, Faculty of Management Sciences \\ Kogi State University, Anyigba, Nigeria \\ basil.nwankwoy2k@yahoo.com +2348033216765 \\ ${ }^{*}$ Corresponding Author
}

\section{Doi:10.5901/mjss.2013.v4n2p595}

\section{Abstract}

The study is a theoretical exposition on the main reason behind the numerous abandoned and uncompleted projects that are now common sights at the third tier level of government in Nigeria, which is the Local Government.It is interesting to note that some of the main reasons often given for the inability of the local governments to play effective role in the development planning and execution process, include: lack of management and technical personnel; inappropriately and inadequately trained manpower; inadequate financial resources, the unstable political structure of local governments, federal government's top-down approach to planning and resources mobilization for development at the local level and poor coordination between the state government's machinery responsible for community development and the local governments which community development projects are located.Similarly, some other general reasons given for non-implementation of development projects and their consequent non-completion or abandonment at the local governments level are:- mismanagement of funds, inflation, unfaigthfulness of contractors, wrong planning, frequent changes of political leadership, inter and intra-communal conflicts, resistance or opposition from community members, lack of funds, ecological constraints etc.Critical and analytical examination of the above reasons commonly adduced for poor project execution and management at the third tier level of government in Nigeria shows that they constitute only symptoms and not the problem. The problem as we identified is lack of adoption of an articulate, programmed and focused framework for project conceptualization, planning execution, monitoring and evaluation.It is therefore, our strong belief and contention that if local governments had adopted the project cycle approach in their development planning and execution, most of the problems identified above would not have arisen. The project cycle approach is strongly recommended for adoption at the third tier level.

\section{Introduction}

The Local Government in Nigeriahave been assigned, among others, the task of promoting development in their locality. The entrenchment of this role in the 1999 constitution of the Federal Republic of Nigeria under the forth schedule was to underscore its importance. Subsequent decrees and guidelines have recognized this role. Specifically Local Governments are require to participate in the;

a. Provision and maintenance of primary, adult and vocational education;

b. Development of agriculture and natural resources, other than exploitation of minerals; and 
c. Provision and maintenance of health services (Obasi, 1998:5)

From a theoretical standpoint, there is absence of innovative programmes and development projects as the Local Governments reduced themselves to doing repetitive things that add little economic and social values to the lives of the people. And this stems from a number of factors. One aspect that is of interest to us is the culture of development planning at the Local Government level.

For quite a long time in the history of development planning in Nigeria, Local Government were excluded. Among the first, second, and third National Development Plan, Local Governments were not integrated. It was only during the fourth National Development Plan (1981 - 85) that Local governments were included in the planning process. But a more meaningful participation started with the introduction of the first National Rolling Plan (1990-92). Under this Rolling Plan, Local Governments were to spend N7 billion. (seeEmezi et al, 1997:1998).

Some of the reasons given for the inability of the Local Governments to play effective role in the development were to spend N7 billion (see Emezi et al, 1997:1998).

Some of the reasons given for the inability of the Local Governments to play effective role in the development planning and execution process include:

a. Lack of management and technical personnel

b. Inappropriately and inadequately trained manpower;

c. Inadequate financial resources;

d. The unstable political structure of Local Governments;

e. Federal Government's top-down approach to planning and resources mobilization for development at the local level; and

f. Poor coordination between the State Government's machinery responsible for community development projects are located (see Orewa, 1991, Emezi et al, 1997 and Obasi,1998).

It is not surprising, therefore that a critical look at the developmental status (profile) of local Governments reveals a dismal picture. Some other reasons given for non-implementation of development projects at the Local Government level include:

a. Mismanagement of funds,

b. Inflation,

c. Unfaithfulness of contractors,

d. Wrong planning,

e. Frequent changes in political leadership,

f. Inter and intra-communal conflict,

g. Resistance or opposition from community members,

h. Non-availability of competent Staff,

i. State government interference,

j. Non-availability of equipment,

k. Ecological constraints,

I. Lack of funds,

m. Wrong site location and

n. Over-pricing by contractors (Emezi et al, 1997 and Obasi,1998).

It is our strong believe and contention that if local governments had adopted the project-cycle approach to their development planning and execution, most of the problems identified above would not have arisen. The main task and focus of this paper, therefore, is to carry out a theoretical reflection on the project cycle. The aim is to assist the Local Government operators to improve on their present level of project identification, formulation, planning, implementation and evaluation, which has largely been responsible for the poor state of development projects at this level of government. For a better understanding of development projects and in order to appreciate the complexity involved in project planning and implementation, a brief theoretical reflection, the meaning of development project and project cycle are considered important.

\section{What is a Development Project?}

According to Gittinger (1981:3) a development project is the cutting edge of development. It is the "smallest operational elements prepared and implemented as a separate entity in a national plan or programme". In other words a development project is the translation of objectives of development plan into tangible and concrete reality. For example, 
lofty goals in National or programmes such as eradication of poverty, ignorance, illiteracy, disease, hunger through the provision of free and functional primary and secondary education, free medical services, well developed infrastructure and easy access to essential farm inputs by rural communities can only be practicable through embarking on various relevant development projects. Thus the main attributes of a development projects according to Diwakwa (1991:1) are as follows:

1. It is specific in its purpose,

2. It has a specific target group within a specific geographic location.

3. It is intended to be executed within a specific time frame i.e it has its own gestation period.

4. It requires technical expertise, materials, machinery and money.

5. It is amenable to changes in the environment - social, cultural, physical, economical and political factors.

Onah, (1997:1), observed that given the importance of development project, the development promoters, leaders and managers must recognize the fact that without successful project identification, formulation (design) and implementation, development plans would remain wishes and developing countries would remain stagnant or even regress. According to Onah (1997) planning a development project is a tedious affair, which requires enormous inputs for if a development project is premised wrongly then what result will short development. This is why a development project passes through a cycle. Just like living organism whose life cycle passes from conception, birth, childhood, adulthood, old age and finally death, projects have their own cycle, but they do not die as such.

\section{The Project Cycle}

A project cycle according to Nwankwo (1998:4), is the stages any development project must through pass through before it can be accepted as properly and adequately executed. According to Diwakwa (1981:3), development projects are diverse in nature. Some are geared to providing tangible goods like road construction project, housing construction project, construction of markets, culvets and digging of cements wells. But, some projects are geared to providing intangible public goods like control of water pollution, provision of security through crime prevention, and public health projects relating to the reduction in air population. However, whatever forms a project takes each project passes through a cycle which, with some little variations, is common to all.

Dennis Rondinelli (1977:5), presents a twelve-stage life-cycle of development projects. Each stage is associated with plans and /or involves plans. The stages are as follows:

1. Project identification and definition

2. Project formulation, preparation and feasibility analysis.

3. Project design.

4. Project appraisal

5. Project selection, negotiation and approval.

6. Project activation and organization.

7. Project implementation.

8. Project supervision, monitoring and control.

9. Project completion or termination.

10. Output diffusion and transition to normal administration.

11. Project evaluation.

12. Follow-up analysis and action.

Warren Baum (1982:1) analysed some of the detailed stages of Rondinelli and presents a simpler project cycle. Each components of the Baum cycle will be discussed as represented in the diagram below: 


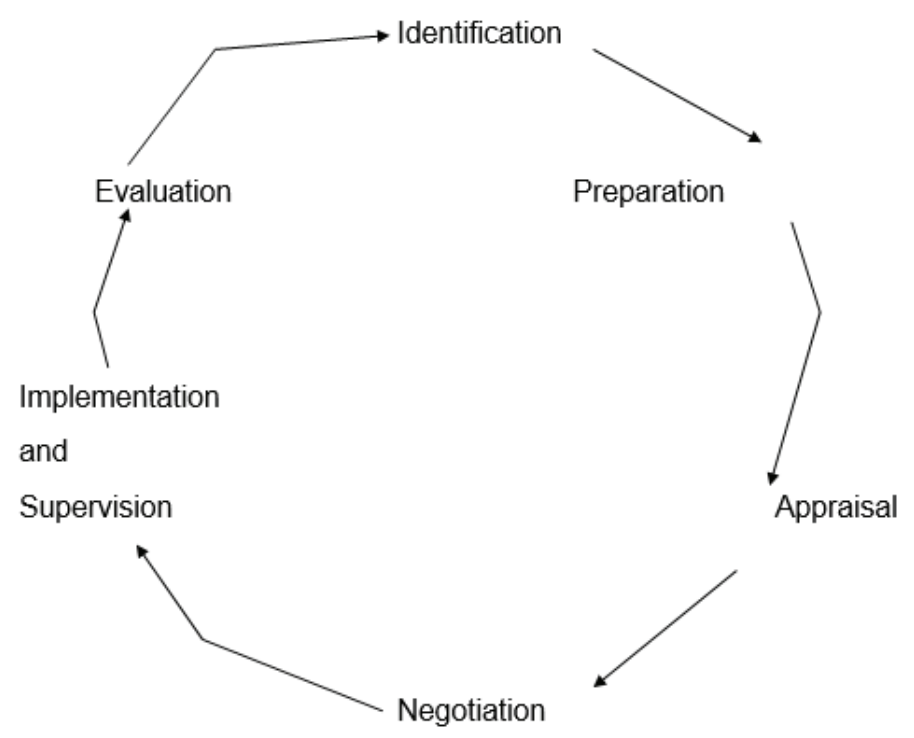

Source: The Baum Cycle as presented by Diwakwa (1991:4) in his paper "The Project Cycle: A General Reflection" Discussion of the Baum cycle is as follows:

\section{Project Identification}

At this stage the problems identified in the development plan for which programmes have been drawn up are paid a special attention. This means that the social demand of the affected communities will be isolated and be paid close attention. Project identification must be necessity involve members of the communities affected or, at least, their acknowledge representatives like Local Government Councilors and Chairmen. But often government identifies problems for communities and designs projects aimed at solving them without the involvement of the beneficiaries. This often results in government solving the wrong problems while over-looking the most pressing social demands of the beneficiary communities.

\section{Project Preparation:}

This is the stage at which concrete proposals on how to meet the identified social demands of the communities are prepared. Available resources will be assessed. Potential resources will be explored and the machinery for implementing the project will be identified. Similarly, the target group, a tentative costing, time-table for activities, and partners to be involved in the project will be identified in the proposal. Project preparation can be done in-house, but when sophisticated machinery and complex activities are involved, outside consultants can be hired to do it. At the Local Government level, such consultations can be technical experts from the state or federal government.

\section{Project Appraisal:}

An appraisal is a screening process which subjects all aspects of the proposed project to scrutiny. Here the concern is with the practicability, workability, or feasibility, economy and viability of the project. Yet again, the entire proposal can be approved without modification.

\section{Project Negotiation:}

At this stage, the approved draft will be marked for sponsorship. This can take the form of defending the budget for the proposal before a budget allocation committee, debating in the council, for negotiating with funding agencies within and 
outside the country. This process intends to pool all the necessary resources, especially funds and to obtain a legal backing for the project before it is implemented.

\section{Project Implementation:}

This constitutes the turning-point of any project. For unless properly implemented project is not worth than a mere wishful expression. At this stage attempts will be made to translate the stated objectives into practical realities by use of available resources. Care must be taken at this stage to minimize delays in action and also to keep financial expenditure to a reasonable limit without compromising the attainment of the objectives of the project. Project implementations at the local government level according to Moris (1982:24) are likely to experience failure due to the following reasons:

a. Projects are identified and designed by outside agencies or the central government and imposed on local communities without recognizing their own peculiarity.

b. Needed resources are not committed in time or when committed are grossly mismanaged.

c. Objectives of the project are vague and immeasurable in quantity terms.

d. The target group or clientele are not clearly defined or integrated into the process of implementation.

e. Projects are motivated more by political expediency than by economic or social viability.

f. Human elements or resources are assigned only secondary important and emphasis is laid on technical and abstract theoretical consideration.

g. Project units and other agencies associated with the project unnecessarily conflicts.

\section{Project Evaluation:}

Evaluation is a process of assessing and analyzing a project with a view to identifying trouble spot or constraints. This exercise can take place either before, during or after the project is implemented. Pre-implementation evaluation is often referred to as appraisal, feasibility study, or extant evaluation. The evaluation that takes place during the process of implementation is called monitoring. But, the evaluation which takes place after the implementation, as reflected in the Baum Cycle, is referred to as impact assessment or expost facto evaluation. Irrespective of which level the evaluation is conducted, it to be done against the back of some criteria, as listed below.

a. Economic efficiency.

b. Social efficiency or effectiveness.

c. Equity in the distribution of resources or income.

d. Impact on the target group in the form of meting their basic needs or empowering them to solve their own problems through their own effort.

It is from these criteria that some specific analytic tools like social cost benefit analysis, cost effectiveness analysis, programme Evaluation Review Technique (PERT), come into play. It is important to observe that project proposal and management at the third tier level of government in Nigeria is abysmal. It has no standard technique or approach. This accounts for the high level of abandoned projects which are prevalent at the local government areas in Nigeria. The adoption of the project cycle management approach the tier level of Government in Nigeria would greatly solve the problem of abandoned projects which are now rampant in most local Government Councils in the country. Therefore, the project cycle approach and management is highly recommended at the third tier level government in Nigeria.

\section{Conclusion}

A clear understanding of the project cycle forms a basis for one's appreciation of the complexity involved in project planning and management. For any project to succeed, activities carried out at the various stages need to be proper and through politicians, administrators and professionals in project planning and implementation. It is also advisable to all governments to take keen interest in evaluating their project so as to minimize cost, overcome constraints and enhance efficiency in their social services delivery.

\section{References}

Bardach, E. (1977), The Implementation Game, Cambridge, Mass: MIT Press.

Conyers, D. and P.Huls (1984), An Introduction to Development Planning in the Third World. New Yew York.John Wiley \& Sons. 
Dlwakwa, H.D (1991), "The Project Cycle: A General Reflection", Paper Presented at a Seminar on project identification, Formulation, Planning, Implementation and Evaluation of Local Government held at Municipal Council, Abuja.

Emezi, C.E. Et al (19970, "Capacity Assessment of Human and Institutional Resources for Planning and Management of Development at Local Government Level in Nigeria: The case of East Central Zone". Final Technical Report Submitted to the United Nations Development Programme (UNDP): Lagos, Nigeria.

Gittinger, J.P. (1996), Economic Analysis of Agricultural Project, Washington, D.C. World Bank.

Idike, A.A. (1996), "Participation of the Nigeria Local Government in National Development Plan, Nigeria Journal of Public Administration and Local Government, Vol 7, No.1.

Keith, Johnson (1996), "Organizational Structures and the Development project Planning sequence" in Public Administration and Development, vol. 4.

Moris, Jon, R (1982), Managing Induced Rural Development, Indiana: International Development Institute.

Nwankwo, B.C. (1998), Management of Foreign aided Programme at the Local Government Level. Paper presented at a Programme Management Workshop organized by lison Consult Associates LTD, held in Owerri, ImoState $12^{\text {th }}-14^{\text {th }}$ August.

Obasi, I.N. (1999), "Development Programme at the Local Government Level. An overview", Paper presented Consult Associates LTD, held in Owerri, ImoState $12^{\text {th }}-14^{\text {th }}$ August.

Okeoye, J.C. (1997), Modern Management Techniques and Development Administration.Abbot Books Ltd, Onitsha, Nigeria.

Onah, F.O. (1997), "Project Planning in the Nigerian Local Government. Assumptions, Processes and Techniques', Paper presented at a seminar on project Identification, formulation, Planning, implementation and Evaluation for Local Government held at Municipal Council, Nigeria (ASCOM).

Orewa, G.O. (1991), Reflections on local Government Development in Nigeria Badagry: Administrative Staff College of Nigeria.

Pressman, J and A. Wildavsky (19790, Implementation, Berkeley: University of California press.

Rondinelli, D.A. (1977), "Planning and Implementing Development Projects: An Introduction" in Dennis A. Rondinelli (ed) Planning Development Projects, Dowden: Hutchinson \& Ross.

Warren, C. Baum (1982), The Project Cycle Washington, D.C.: World Bank.

Weiss, Dicker (1980), "Planning and Evaluation of Development Programmes", Ekistics, Vol. 284 September/October. 